\title{
Use of Expired Air Carbon Monoxide Testing in Clinical Tobacco Treatment Settings
}

\author{
Adam O. Goldstein, MD, MPH; Stephanie P. Gans, MSW; Carol Ripley-Moffitt, MDiv, CTTS; Chris Kotsen, PsyD, CTTS; \\ and Matthew Bars, MS, CTTS
}

Carbon monoxide ( $\mathrm{CO}$ ) testing is considered an easy, noninvasive, and objective contribution to the assessment of smoking behavior, as $\mathrm{CO}$ is rapidly absorbed into the bloodstream when lit cigarettes or cigars are inhaled. CO testing is a medically important billable outpatient service that can contribute to sustainability of face to face tobacco use treatment services by clinicians. This article reviews research on the clinical use of CO testing to provide biomedical feedback in assessing smoking behavior, educating smokers on tobacco health effects, assisting with treatment planning, and as a motivational tool to encourage people to become tobacco free. Further research can focus on how to best incorporate $\mathrm{CO}$ testing into clinical practice, including more research on outcomes and methods to ensure that insurers reimburse for testing and improved ways to use $\mathrm{CO}$ testing to initiate attempts to quit tobacco use, to maintain cessation, and to prevent relapse.

CHEST 2018; 153(2):554-562

KEY WORDS: exhaled carbon monoxide; smoking; smoking cessation; tobacco

Carbon monoxide $(\mathrm{CO})$ is a clear odorless gas that reduces oxygen-carrying capacity in the blood. CO is produced by oxidation of carbon-containing compounds, such as those that occur with combustion of cigarettes or cigars. When smoke from combustible tobacco smoke is inhaled, CO is rapidly absorbed into the bloodstream. Although environmental sources of $\mathrm{CO}$ exist (eg, from incomplete combustion of carbon, such as motor vehicle exhaust, pollution, or malfunctioning furnaces during the winter ${ }^{1,2}$ ), tobacco smoking is the major source of elevated $\mathrm{CO}$ levels in the bloodstream. In contrast, $\mathrm{CO}_{2}$ is the principal product of combustion of fossil fuels.
CO testing is considered an easy, noninvasive, and objective contribution to the assessment of smoking behavior. ${ }^{3} \mathrm{CO}$ testing measures the amount of $\mathrm{CO}$ in endtidal expired breath as a marker for smoking status, and it is an increasingly important clinical tool for biochemically assessing and confirming smoking status and for use in counseling people who smoke cigarettes to quit smoking. ${ }^{4,5} \mathrm{CO}$ monitors measure the amount of $\mathrm{CO}$ expired in parts per million (ppm). The level of CO in ppm in the breath corresponds to the percent of carboxyhemoglobin or the percentage of blood cells carrying $\mathrm{CO}$ instead of oxygen. ${ }^{4}$ Most CO in the blood is bound to
ABBREVIATIONS: $\mathrm{CO}=$ carbon monoxide; $\mathrm{COHb}=$ carboxyhemoglobin; $\% \mathrm{COHb}=$ percent carboxyhemoglobin

AFFILIATIONS: From the Department of Family Medicine (Dr Goldstein; and Mss Gans and Ripley-Moffitt), University of North Carolina, Chapel Hill, NC; the Robert Wood Johnson University Hospital Somerset (Dr Kotsen), Somerville, NJ; and the IQuit Smoking Program (Mr Bars), Jersey City Medical Center, Jersey City, NJ.
CORRESPONDENCE TO: Adam O. Goldstein, MD, MPH, University of North Carolina School of Medicine, 590 Manning Dr, CB 7595, Chapel Hill, NC 27599; e-mail: aog@med.unc.edu

DoI: https://doi.org/10.1016/j.chest.2017.11.002 
hemoglobin. The percentage of fetal carboxyhemoglobin $(\mathrm{COHb})$ can also be calculated using maternal expired CO. ${ }^{6}$ People who smoke cigarettes have higher levels of $\mathrm{CO}$ in expired breath, and $\mathrm{CO}$ monitors report both $\mathrm{CO}$ and $\mathrm{COHb}$ levels. ${ }^{4}$

As a billable outpatient service in the United States, CO testing can contribute to sustainability of face to face tobacco use treatment services. CO monitors can provide biomedical feedback to assess smoking behavior, educate smokers about tobacco health effects, assist with treatment planning, and serve as a motivational tool for people to become tobacco free. This paper reviews current use and research on $\mathrm{CO}$ testing in clinical tobacco treatment settings.

\section{CO Assessment in Clinical Situations}

$\mathrm{CO}$ testing is used in clinical and research settings as an objective noninvasive way to assess smoking behavior. ${ }^{3}$ CO levels in expired air are correlated with levels of self-reported cigarette or cigar smoking. ${ }^{3} \mathrm{CO}$ has a half-life of 5 to 6 hours in the body, ${ }^{7}$ and CO levels return to normal after 24 to 48 hours of not smoking. ${ }^{1}$

In research studies of people who smoke, $\mathrm{CO}$ levels $>10$ ppm in expired breath indicate current smoking, whereas CO levels $<10 \mathrm{ppm}$ will often be interpreted as evidence of smoking cessation. ${ }^{7-9} \mathrm{CO}$ measurements are also used clinically to predict severity of nicotine dependence and cravings for people attempting to quit. ${ }^{4}$ One study found that $\mathrm{CO}$ levels in expired air could predict whether smokers with normal lung function had smoked in the past 8 hours. ${ }^{7} \mathrm{CO}$ levels at or $<12 \mathrm{ppm}$ predicted smoking abstinence in the previous 8 hours. ${ }^{7}$ $\mathrm{CO}$ testing using these thresholds may not easily distinguish occasional smokers from nonsmokers. ${ }^{8}$ Therefore, in some clinical settings, a threshold of $6 \mathrm{ppm}$ provides additional assurance of complete abstinence. ${ }^{1,10}$

$\mathrm{CO}$ and $\mathrm{COHb}$ levels are also determined by several endogenous (eg, normal metabolism of heme proteins), environmental (eg, exposure to motor vehicle exhaust), product (eg, different types of combustible tobacco products), medical (eg, certain diseases), and individual factors. For instance, different methods of smoking tobacco products (eg, hookah, cigars, "little" cigars, and chillum [conical pipe] smoking) result in different and often higher levels of $\mathrm{CO} .{ }^{11}$ Smoking marijuana will elevate exhaled CO. ${ }^{12}$ Patients with COPD, OSA, or asthma, as well as those who live in heavily urbanized areas, have higher CO levels, even if they do not smoke. ${ }^{8,13,14}$ To assess smoking behavior in such patients, a cutoff point of $10 \mathrm{ppm}$ for patients with asthma and $11 \mathrm{ppm}$ for patients with COPD has been proposed. ${ }^{15}$ Conflicting evidence exists about the presence of elevated levels of exhaled $\mathrm{CO}$ in patients with diabetes mellitus. One study found that exhaled CO levels were higher in people with diabetes and correlated with increases in blood glucose levels. ${ }^{16}$ A more recent study found that this was not the case using newer $\mathrm{CO}$ monitors. ${ }^{17} \mathrm{CO}$ levels may be elevated in people with very high levels of secondhand smoke exposure (eg, in homes, cars, hookah bars), or exhaust from combustible materials (eg, a faulty furnace). This includes people whose occupations expose them to exhaust and smoke, such as firefighters, toll collectors, tractor drivers, road asphalt workers, and those who spend time along roads or in heavily polluted urban areas. ${ }^{13,18}$

Individual differences can also affect $\mathrm{CO}$ levels. For instance, a reduced effort (due to respiratory muscle fatigue or lack of desire, motivation, or ability to inhale and exhale deeply) will reduce CO levels. ${ }^{19}$ Hyperventilation and exercise can also lower $\mathrm{CO}$ levels. ${ }^{20}$ Although these factors may make it more difficult to make comparisons of $\mathrm{CO}$ levels across patients, consistently elevated levels within individual patients who use combustible tobacco products likely demonstrates higher exposure to the toxicity of these products. ${ }^{8,10,18}$ Even if a clinician makes an adjustment for those with heavy environmental or endogenous exposure, the most frequent reason for a $\mathrm{CO}$ level to be high in someone who previously smoked is that they have returned to smoking, either socially or more heavily. ${ }^{18}$ Some patients may be resistant to telling their providers they have returned to smoking out of fear of disappointment, judgment, or even shame. ${ }^{21}$

Higher levels of $\mathrm{CO}$ and nicotine in the blood may even correlate with the nature of smoking behavior. For example, depth of inhalation, number of puffs, and other measures of smoking topography can affect $\mathrm{CO}$ levels as much as the number of cigarettes smoked. ${ }^{4,22}$ Some people reduce the number of cigarettes they smoke but smoke them more efficiently, resulting in similar CO levels. ${ }^{4,23} \mathrm{CO}$ levels fluctuate throughout the day, increasing after each cigarette and decreasing between cigarettes. $^{7,23,24}$ The effectiveness of some medications or products marketed as cessation aides can be assessed using $\mathrm{CO}$ testing. For instance, some have used $\mathrm{CO}$ testing to assess quitting of combustible tobacco products among groups of subjects who have switched to vaping and electronic cigarettes. ${ }^{25}$ Even though a patient continues to smoke and use nicotine 
replacement therapy or other pharmacotherapy for smoking cessation, such medications can bring about a reduction in expired CO. ${ }^{4}$ In one study of patients using varenicline, regardless of the number of cigarettes smoked at the time, a decrease in $\mathrm{CO}$ in expired air was significant in predicting future abstinence from smoking. ${ }^{4}$ In another study, reductions in cigarettes per day, aided by nicotine replacement therapy, were verified by reductions in expired $\mathrm{CO} .^{26}$ Increasingly, some physicians, such as orthopedic surgeons, require smoking cessation prior to major elective surgery, such as joint replacement, and use CO measures to document abstinence. ${ }^{27}$

\section{CO Testing and Patient Education in Tobacco Use}

CO testing can facilitate patient education about the effects of smoking, as it is a personalized measurement of how smoking affects the oxygen-carrying capacity of the blood. ${ }^{4}$ Although some people are aware of CO and its negative health effects, the personalized measure of $\%$ $\mathrm{COHb}$ demonstrates that they may be experiencing, or are at risk for, those effects. ${ }^{6}$ Testing can offer "seeing is believing" feedback on one consequence of smoking, decreased oxygen capacity, which can be related to fatigue, low energy, shortness of breath, windedness, and other cardiovascular symptoms. ${ }^{6,28}$ As patients reduce tobacco use, clinical experience shows that regular $\mathrm{CO}$ testing can build patient confidence, especially when increased oxygen levels are linked with better breathing or higher energy levels. ${ }^{29}$ This clinical experience "of beating the machine" and having very low $\mathrm{CO}$ readings becomes a metaphor for breaking free of tobacco addiction while sustaining quantitative and tangible clinical progress.

CO testing may be particularly useful in several specialized settings outside the primary care clinic. For instance, those with comorbid smoking and mental health conditions often smoke at much higher rates than the general population; in such patients, the regular use of CO testing has increased patients' knowledge of CO and its effects. ${ }^{28} \mathrm{CO}$ monitors are also used outside the clinic in health fairs or other public health settings because they are portable and noninvasive. Some $\mathrm{CO}$ monitors automatically convert $\mathrm{COHb}$ into fetal $\mathrm{COHb}$, which could be useful in providing education for pregnant women in any clinical setting. ${ }^{30}$ The development of phone applications and other technology that can incorporate CO testing represents an opportunity for further patient education. ${ }^{31}$

\section{CO Testing and Motivation for Smoking} Cessation

$\mathrm{CO}$ testing may be particularly useful to consider as an adjunct to behavioral strategies to increase motivation to quit smoking. Such testing should be of interest to not only primary care clinicians but also specialists, such as pulmonologists and cardiologists, who see high numbers of patients who smoke. ${ }^{32}$ Tobacco treatment specialists already regularly use $\mathrm{CO}$ testing in face to face treatment settings to emphasize the benefits of reduced $\mathrm{CO}$ measures, even from one day of abstinence.

$\mathrm{CO}$ testing may also motivate repeated attempts to quit smoking in those who continue to smoke. ${ }^{30} \mathrm{CO}$ testing should work best when combined with counseling and other forms of support. ${ }^{29}$ A study of behavioral change techniques used in English smoking cessation programs found that programs that included CO testing tended to have better quit rates, and the great majority of the participants in the United Kingdom's National Health Services Smoking Cessation Centers receive CO testing. ${ }^{33}$ One small study, using $\mathrm{CO}$ testing without counseling, showed that using the $\mathrm{CO}$ monitor regularly for 2 weeks increased the motivation to quit as well as decreased smoking. ${ }^{34}$ A randomized controlled trial of $\mathrm{CO}$ testing and feedback with brief counseling, compared with brief counseling alone, showed increased threat appraisal and intention to stop smoking in the next month for those who received CO testing. ${ }^{35}$ In addition, participants with high self-efficacy who received $\mathrm{CO}$ testing demonstrated higher rates of cessation. ${ }^{36}$ A qualitative study of those receiving counseling by tobacco treatment specialists reported that $\mathrm{CO}$ testing was believable, helped them understand the impact of smoking on their health, and was motivational for them in attempts to quit. ${ }^{37}$ In contrast, a randomized controlled trial of CO testing did not show statistically significant improved outcomes for long-term motivation, ${ }^{35}$ and a review of a small number of studies of biomedical feedback, including $\mathrm{CO}$ testing, indicated that there was insufficient research to fully determine the impact of CO testing on cessation outcomes in routine clinical practice.

Some groups may receive more benefit than others from routine CO testing. ${ }^{26}$ For instance, a qualitative study of pregnant women reported that visual feedback from CO monitoring offered routinely at the time of an antenatal ultrasonographic examination improved their motivation to quit. ${ }^{38}$ Other studies have examined the feasibility of self-monitoring CO levels through the 
Internet or smart phones to assist individuals with cessation. One study of mobile phone $\mathrm{CO}$ monitors found them to be effective in determining current smoking status. ${ }^{31}$ Another study combined CO testing with an Internet intervention, with rewards contingent on lower CO levels as a way to increase smoking cessation..$^{39}$ During the period of CO testing, abstinence increased, but at 3- and 6-month follow-ups, those who had used CO testing were not more likely to be abstinent than the control group. ${ }^{40}$ This research, however, was an Internet-based study, paid participants to quit, and did not use $\mathrm{CO}$ as part of face to face treatment. Further research, particularly studies with high methodological rigor and larger sample sizes, is necessary to see how CO testing, in collaboration with other technologies, can best increase motivation and outcomes in smoking cessation. $^{29,39}$

\section{Purchasing and Using a CO Monitor}

Numerous CO monitors are available, with varying accuracy levels. ${ }^{40}$ Although each model is slightly different, they are easy to use and require minimal maintenance. ${ }^{30,41-50}$ Most need to be calibrated about twice a year to maintain accuracy and avoid false readings. Wiping monitors and changing mouthpiece mounts are standard infection control measures that may help prevent infections. ${ }^{44,45,49,50}$ Most CO monitors work similarly, but instructions vary slightly in procedure. Some of the most commonly used CO monitors for tobacco treatment settings are the Bedfont Smokerlyzer, the MicroCO Meter, and the BreathCO Monitor from Vitalograph. Other monitors exist for use in emergency settings or for children. ToxCO by Bedfont is one such monitor. ${ }^{47}$ The price range for purchase is considerable (range $\$ 60-\$ 1,200$ ) and varies in large part based on what is included with the purchase and maintenance. A comparison of commonly used CO monitors can be found in Table 1, and a protocol of use in one tobacco treatment program is seen in Appendix 1.

$\mathrm{CO}$ testing requires the active participation of the patient. As part of the standard protocol, patients are asked to take a deep breath and hold it for 15 seconds before making a seal of the disposable mouthpiece and exhaling. For patients who may have pulmonary or cardiac disorders (eg, COPD, asthma, heart failure) the breath is held for as long as they are able before exhaling.

The sensitivity and specificity (Table 1) of different monitoring devices vary. ${ }^{41}$ Since any exposure to $\mathrm{CO}$ will be measured, secondhand smoke exposure or exposure in home or work heating systems or vehicle exhaust, as well as any other substance smoked (eg, marijuana), will need to be considered, especially for those who report abstinence but have higher readings. ${ }^{18}$

\section{Calibration and Sanitation}

All CO monitors have similar calibration and cleaning guidelines. ${ }^{30,41-50}$ All monitors have detachable tubes that catch $\mathrm{CO}$, preventing the exhaled air from being inhaled again. The tubes have various names: $\mathrm{D}$ piece, $\mathrm{T}$ valve, and mouthpiece adapter. Manufacturers recommend following standard cleaning instructions, including regularly replacing the tubes, usually once a month. Most monitors use disposable cardboard mouth pieces to attach to the tube. A new cardboard mouthpiece must be used for each CO test. Some monitors (eg, piCO Smokerlyzer) have moved to plastic rather than cardboard mouthpieces. Most of the monitors require recalibration with a kit every 6 months. Some of the monitors remind the user when a calibration or tube change is due. Having the proper accessories, calibration, and sanitation practices is essential to accurate readings, and maintenance of the device.

\section{Practical Issues to Consider in Billing for CO Testing (ie, Expired Gas Collection)}

$\mathrm{CO}$ testing is a billable outpatient face to face service in the United States under the name expired gas collection. The Current Procedural Terminology code for this service is 94250 , or expired gas collection, quantitative, single procedure. Under the International Classification of Diseases, tenth revision, regulations in the United States, diagnoses that support medical necessity for this Current Procedural Terminology include most common tobacco-related pulmonary (eg, asthma), cardiac (eg, heart failure), and infectious (eg, chronic bronchitis) conditions; many other common symptoms of smoking (eg, cough, wheezing, and shortness of breath); and even abnormal lung findings on examination..$^{51}$ Although reimbursement for procedural services is a function of insurance plan details and varies widely, coverage for CO testing in clinical situations should proceed in a manner similar to reimbursement for other pulmonary diagnostic testing and therapies, such as fractional exhaled nitric oxide. ${ }^{52}$ Reimbursement rates in the United States in 2017 for CO testing average close to $\$ 30^{53}$ and may range from around $\$ 20$ for Medicaid to $>\$ 60$ for some private insurance companies. Although tobacco cessation services (individual/group) have been 
TABLE 1] Brands and Characteristics of CO Monitors

\begin{tabular}{|c|c|c|c|c|c|c|c|c|}
\hline Product & CO Check $+^{34}$ & MicroCO 35 & SmokeCheck ${ }^{36}$ & Smokerlyzer iCO ${ }^{37}$ & Smokerlyzer Micro+ ${ }^{25}$ & $\begin{array}{l}\text { Smokerlyzer } \\
\text { piCO+ }{ }^{39}\end{array}$ & $\begin{array}{l}\text { Smokerlyzer } \\
\text { piCObaby }{ }^{25}\end{array}$ & BreathCo $^{38}$ \\
\hline Manufacturer & Micro Direct & Micro Direct & Micro Direct & Bedfont & Bedfont & Bedfont & Bedfont & Vitalograph \\
\hline Price $^{40-42}$ & $\$ 695.00$ & $\$ 1,195.00$ & $\$ 495.00$ & $\$ 60.00$ & $\$ 1,190.00$ & $\$ 620.00$ & $\$ 650.00$ & $\$ 1,254.00$ \\
\hline $\begin{array}{l}\text { What's } \\
\text { included? }\end{array}$ & $\begin{array}{l}\text { CO Check+ meter, } \\
\text { mouthpiece } \\
\text { adapter, } \\
\text { reducing } \\
\text { connector, 9-V } \\
\text { battery, } 4 \\
\text { disposable } \\
\text { mouthpieces, } \\
\text { carry pouch }\end{array}$ & $\begin{array}{l}\text { Micro CO meter, } \\
\text { mouthpiece } \\
\text { adapter, } \\
\text { reducing } \\
\text { connector, } \\
9-\mathrm{V} \text { battery, } 4 \\
\text { disposable } \\
\text { mouthpieces, } \\
\text { calibration } \\
\text { tool, carrying } \\
\text { case }\end{array}$ & $\begin{array}{l}\text { SmokeCheck } \\
\text { meter, } \\
\text { mouthpiece } \\
\text { adapter, } \\
\text { reducing } \\
\text { connector, } \\
9-\mathrm{V} \text { battery, } \\
4 \text { disposable } \\
\text { mouthpieces, } \\
\text { calibration } \\
\text { tool, carrying } \\
\text { case }\end{array}$ & $\begin{array}{l}\text { pico Smokerlyzer, } \\
\text { carrying pouch, } \\
1 \text { headphone cable, } \\
\text { quick start guide }\end{array}$ & $\begin{array}{l}\text { Micro+ Pro CO monitor, } \\
\text { COdata+ database } \\
\text { software, USB cable, } \\
3 \text { AA batteries, } \\
\text { monitor carrying } \\
\text { case, carrying bag, } \\
\text { maternity chart, } \\
\text { interpretation } \\
\text { poster, } 1 \text { Intro Pack } \\
1 \text { SteriBreathD-Piece, } \\
\text { SteriBreathmouthpiece, } \\
\text { quick-start guide }\end{array}$ & $\begin{array}{l}\text { piCO+ monitor, } \\
\text { monitor } \\
\text { zippered case, } \\
\text { zippered soft } \\
\text { canvas case, } \\
\text { manual, } \\
\text { infection } \\
\text { control guide, } \\
2 \text { cOdata+ } \\
\text { database } \\
\text { software CD } \\
\text { with USB } \\
\text { cable, AA } \\
\text { batteries, } \\
\text { posters, Intro } \\
\text { Pack } \\
\text { (SteriBreathD- } \\
\text { piece, } \\
\text { mouthpiece) }\end{array}$ & $\begin{array}{l}\text { Micro+baby CO } \\
\text { monitor, } \\
\text { COdata+ } \\
\text { database } \\
\text { Software, } \\
\text { USB cable, } 3 \\
\text { AA batteries, } \\
\text { monitor } \\
\text { carrying case, } \\
\text { carrying bag, } \\
\text { maternity } \\
\text { chart, } \\
\text { interpretation } \\
\text { poster, Intro } \\
\text { Pack (1 } \\
\text { SteriBreath } \\
\text { D-piece, 1 } \\
\text { SteriBreath } \\
\text { mouthpiece), } \\
\text { quick-start } \\
\text { guide }\end{array}$ & $\begin{array}{l}\text { Breathco } \\
\text { monitor, 9-V } \\
\text { battery, } \\
\text { unclear what } \\
\text { other } \\
\text { accessories } \\
\text { may be } \\
\text { included. } \\
\text { Requires } \\
\text { calibration } \\
\text { kit, monitor } \\
\text { mouthpieces, } \\
\text { and sampling } \\
\text { T connector }\end{array}$ \\
\hline Typical use & $\begin{array}{l}\text { Smoking } \\
\text { cessation }\end{array}$ & $\begin{array}{l}\text { Research, } \\
\text { smoking } \\
\text { cessation }\end{array}$ & $\begin{array}{l}\text { Low-cost } \\
\text { screening } \\
\text { tool for } \\
\text { cigarette } \\
\text { consumption }\end{array}$ & $\begin{array}{l}\text { Smoking cessation } \\
\text { motivation tool }\end{array}$ & $\begin{array}{l}\text { Research, smoking } \\
\text { cessation }\end{array}$ & $\begin{array}{l}\text { Smoking } \\
\text { cessation, } \\
\text { research }\end{array}$ & $\begin{array}{l}\text { Smoking } \\
\text { cessation, } \\
\text { research, } \\
\text { motivational } \\
\text { tool for } \\
\text { expectant } \\
\text { mothers }\end{array}$ & $\begin{array}{l}\text { Research, } \\
\text { smoking } \\
\text { cessation }\end{array}$ \\
\hline $\begin{array}{l}\text { Breath hold } \\
\text { countdown }\end{array}$ & $\begin{array}{l}\text { On screen 15-s } \\
\text { countdown }\end{array}$ & $\begin{array}{l}\text { 20-s breath hold } \\
\text { countdown on } \\
\text { screen }\end{array}$ & $\begin{array}{l}\text { No countdown, } \\
\text { but a buzzer } \\
\text { sounds } 20 \mathrm{~s} \\
\text { after auto- } \\
\text { zero function }\end{array}$ & 15-s countdown on phone & $\begin{array}{l}\text { User-adjustable } \\
\text { countdown timer with } \\
\text { sounder }\end{array}$ & $\begin{array}{l}\text { 15-s countdown } \\
\text { timer with } \\
\text { sounder }\end{array}$ & $\begin{array}{l}\text { 15-s countdown } \\
\text { timer with } \\
\text { sounder }\end{array}$ & $\begin{array}{l}\text { No countdown, } \\
\text { patient holds } \\
\text { breath for } 10 \mathrm{~s}\end{array}$ \\
\hline Result format & $\begin{array}{l}\text { Measures ppm of } \\
\text { CO and \% } \\
\text { COHb }\end{array}$ & $\begin{array}{l}\text { Measures ppm } \\
\text { of CO and \% } \\
\text { COHb, lights } \\
\text { indicating CO } \\
\text { level and } \\
\text { alarm }\end{array}$ & $\begin{array}{l}\text { Measures ppm } \\
\text { of CO, lights } \\
\text { indicating CO } \\
\text { level and } \\
\text { alarm }\end{array}$ & $\begin{array}{l}\text { Results are broken } \\
\text { into ppm ranges, 0-6, } \\
7-10,11-15,16-20, \\
21-25,26-30, \text { and } 31+, \\
\text { which are } \\
\text { assigned levels of } \\
\text { nicotine dependence }\end{array}$ & $\begin{array}{l}\text { Measurement of ppm, } \\
\% \mathrm{COHb} \text {, and \% } \\
\text { FCOHb, lights and } \\
\text { alarm, can measure } \\
\mathrm{CO} \text { in ambient air } \\
\text { as well }\end{array}$ & $\begin{array}{l}\% \mathrm{COHb} \text { and } \\
\text { ppm, lights } \\
\text { and alarm }\end{array}$ & $\begin{array}{l}\text { \%COHb, and } \\
\% \text { FCOHb, and } \\
\text { ppm }\end{array}$ & $\begin{array}{l}\mathrm{CO}(\mathrm{ppm}) \text { in } \\
\text { expired air, } \\
\text { use } \\
\text { conversion } \\
\text { chart to } \\
\text { match ppm } \\
\text { to COHb }\end{array}$ \\
\hline $\begin{array}{l}\text { Concentration } \\
\text { range }\end{array}$ & 0-99 ppm & $0-300 \mathrm{ppm}$ & $0-100 \mathrm{ppm}$ & $0-100 \mathrm{ppm}$ & $0-500 \mathrm{ppm}$ & 0-150 ppm & $0-150 \mathrm{ppm}$ & 0-199 ppm \\
\hline
\end{tabular}


TABLE 1 ] (Continued)

\begin{tabular}{|c|c|c|c|c|c|c|c|c|}
\hline Product & CO Check $+{ }^{34}$ & MicroCO 35 & SmokeCheck ${ }^{36}$ & Smokerlyzer iCO ${ }^{37}$ & Smokerlyzer Micro+ ${ }^{25}$ & $\begin{array}{l}\text { Smokerlyzer } \\
\text { piCO+ }\end{array}$ & $\begin{array}{l}\text { Smokerlyzer } \\
\text { piCObaby }\end{array}$ & BreathCO 38 \\
\hline $\begin{array}{r}\text { Sensitivity, } \\
\text { accuracy }\end{array}$ & $1 \mathrm{ppm} \pm 2 \%$ & $\begin{array}{l}1 \mathrm{ppm} \\
\pm 5 \% \text { of reading } \\
\text { or } 1 \mathrm{ppm}, \\
\text { whichever is } \\
\text { greater }\end{array}$ & $\begin{array}{l}1 \mathrm{ppm} \\
\pm 5 \% \text { of reading } \\
\text { or } 1 \mathrm{ppm}, \\
\text { whichever is } \\
\text { greater }\end{array}$ & $1 \mathrm{ppm} \pm 15 \%$ & $1 \mathrm{ppm}<3 \%$ & $1 \mathrm{ppm}<3 \%$ & $1 \mathrm{ppm} \pm 5 \%$ & $1 \mathrm{ppm} \pm 3 \mathrm{ppm}$ \\
\hline Display & $\begin{array}{l}3.5 \text { digit custom } \\
\text { LCD }\end{array}$ & $\begin{array}{l}3.5 \text { digit custom } \\
\text { LCD }\end{array}$ & Custom LCD & $\begin{array}{l}\text { Displays on } \\
\text { user's phone }\end{array}$ & Full-color touch screen & $\begin{array}{l}\text { Full-color LCD } \\
\text { screen }\end{array}$ & $\begin{array}{l}\text { Full-color touch } \\
\text { screen }\end{array}$ & $\begin{array}{l}3.5 \text { digit } \\
1 / 2 \text {-inch LCD }\end{array}$ \\
\hline Sound & $\begin{array}{l}\text { Alarm at }>72 \\
\quad p p m\end{array}$ & $\begin{array}{l}\text { Alarm at }>72 \\
\text { ppm }\end{array}$ & $\begin{array}{l}\text { Alarm at } 20 \mathrm{ppm} \\
\text { and more }\end{array}$ & No & $\begin{array}{l}\text { Yes, can be turned } \\
\text { on and off }\end{array}$ & $\begin{array}{l}\text { Yes, can be } \\
\text { turned on and } \\
\text { off }\end{array}$ & $\begin{array}{l}\text { Yes, can be } \\
\text { turned on and } \\
\text { off }\end{array}$ & $\ldots$ \\
\hline Software & $\ldots$ & $\begin{array}{l}\text { Interacts with } \\
\text { COBRA } \\
\text { software, for } \\
\text { use in } \\
\text { tracking } \\
\text { results, can } \\
\text { create CO } \\
\text { report for } \\
\text { client }\end{array}$ & $\cdots$ & $\begin{array}{l}\text { Interacts with the } \\
\text { Smokerlyzer } \\
\text { application available } \\
\text { for download onto } \\
\text { a smart phone } \\
\text { or tablet }\end{array}$ & $\begin{array}{l}\text { Interacts with included } \\
\text { CO Data + software } \\
\text { for database results } \\
\text { storage and charting }\end{array}$ & $\begin{array}{l}\text { Interacts with } \\
\text { included CO } \\
\text { Data+ } \\
\text { software for } \\
\text { database } \\
\text { results storage } \\
\text { and charting }\end{array}$ & $\begin{array}{l}\text { Interacts with } \\
\text { included CO } \\
\text { Data+ } \\
\text { software for } \\
\text { database } \\
\text { results } \\
\text { storage and } \\
\text { charting }\end{array}$ & $\ldots$ \\
\hline Battery & $\begin{array}{l}\text { User-replaceable } \\
\text { 9-V battery }\end{array}$ & $\begin{array}{l}\text { User-replaceable } \\
9-\mathrm{V} \text { battery }\end{array}$ & $\begin{array}{l}\text { User- } \\
\text { replaceable } \\
\text { 9-V battery }\end{array}$ & Powered by phone & $\begin{array}{l}\text { User-replaceable } 3 \text { AA } \\
\text { batteries }\end{array}$ & $\begin{array}{l}\text { User-replaceable } \\
2 \text { AA batteries }\end{array}$ & $\begin{array}{l}\text { User- } \\
\text { replaceable } 2 \\
\text { AA batteries }\end{array}$ & $\begin{array}{l}\text { User- } \\
\text { replaceable } \\
\text { 9-V battery }\end{array}$ \\
\hline Warranty & $1 \mathrm{y}$ & Unknown & Unknown & $6 \mathrm{mo}$ & $5 y$ & $5 y$ & $5 y$ & $1 y$ \\
\hline Support & $\begin{array}{c}\text { Telephone } \\
\text { support }\end{array}$ & $\begin{array}{c}\text { Telephone } \\
\text { support }\end{array}$ & $\begin{array}{c}\text { Telephone } \\
\text { support }\end{array}$ & Telephone support & Telephone support & $\begin{array}{c}\text { Telephone } \\
\text { support }\end{array}$ & $\begin{array}{c}\text { Telephone } \\
\text { support }\end{array}$ & $\begin{array}{l}\text { Telephone } \\
\text { support }\end{array}$ \\
\hline Maintenance & $\begin{array}{l}\text { 9-V battery } \\
\text { replaced } \\
\text { periodically, } \\
\text { calibration } \\
\text { every } 6 \mathrm{mo}, \\
\text { mouthpiece } \\
\text { adapter can be } \\
\text { cleaned and } \\
\text { must be } \\
\text { replaced after } \\
250 \text { tests, CO } \\
\text { sensor } \\
\text { replaced every } \\
2 \text { y }\end{array}$ & $\begin{array}{l}\text { 9-V battery lasts } \\
\text { for up to } \\
2,000 \text { tests, } \\
\text { calibration } \\
\text { every } 6 \mathrm{mo}, \\
\text { mouthpiece } \\
\text { adapter can } \\
\text { be cleaned } \\
\text { and must be } \\
\text { replaced } \\
\text { periodically }\end{array}$ & $\begin{array}{l}\text { Calibration } \\
\text { every } 6 \text { mo, } \\
\text { mouthpiece } \\
\text { adapter can } \\
\text { be cleaned } \\
\text { and must be } \\
\text { replaced } \\
\text { periodically }\end{array}$ & $\begin{array}{l}\text { Lasts for } 200 \text { tests } \\
\text { or } 3 y \text { (whichever } \\
\text { is sooner) }\end{array}$ & $\begin{array}{l}\text { Cleaning the D-piece } \\
\text { and sterilizing } \\
\text { exterior of monitor, } \\
\text { replacing batteries, } \\
\text { changing D-piece } \\
\text { every } 30 \mathrm{~d} \text {; sensor } \\
\text { should be replaced } \\
\text { every } 5 \text { y, periodic } \\
\text { calibration required }\end{array}$ & $\begin{array}{l}\text { Wiping the } \\
\text { D-piece and } \\
\text { exterior of } \\
\text { monitor, } \\
\text { replacing } \\
\text { batteries, } \\
\text { changing } \\
\text { D-piece every } \\
30 \text { d; Sensor } \\
\text { should be } \\
\text { replaced every } \\
5 \text { y, periodic } \\
\text { calibration } \\
\text { required }\end{array}$ & $\begin{array}{l}\text { Wiping the } \\
\text { D-piece and } \\
\text { exterior of } \\
\text { monitor, } \\
\text { replacing } \\
\text { batteries, } \\
\text { changing } \\
\text { D-piece every } \\
30 \text { d; Sensor } \\
\text { should be } \\
\text { replaced } \\
\text { every } 5 \mathrm{y} \text {, } \\
\text { periodic } \\
\text { calibration } \\
\text { required }\end{array}$ & $\begin{array}{l}\text { Replace } \\
\text { sampling-T } \\
\text { after } 50 \text { uses, } \\
\text { annual } \\
\text { calibration }\end{array}$ \\
\hline
\end{tabular}

$\mathrm{CO}=$ carbon monoxide; $\mathrm{LCD}=$ liquid crystal display; \% $\mathrm{COHb}=$ percent carboxyhemoglobin; \%FCOHb = percent fetal carboxyhemoglobin; ppm = parts per million. 
reimbursed as a preventive service and typically covered at $100 \%$ (ie, no cost sharing [coinsurance, copays, deductibles]) for the majority of patients, $\mathrm{CO}$ testing is typically considered a diagnostic service and therefore is usually covered with a small coinsurance patient cost-sharing responsibility. As payers may have variable reimbursement policies, if the service is denied by an insurance plan or is not covered, the financial responsibility for unpaid charges would fall to the patient.

\section{Limitations to CO Testing}

Although CO testing is an objective contribution to the assessment of smoking behavior for combustible tobacco products (eg, cigarettes, cigars, water pipes), it is not a useful tool to measure consumption of noncombustible tobacco products. For instance, to objectively measure electronic cigarette or smokeless tobacco use, other biochemical assessments, such as cotinine or nicotine levels, may be indicated, although they are not routinely used in clinical practice. In patients who use multiple tobacco products (eg, cigarettes and electronic cigarettes), $\mathrm{CO}$ testing would demonstrate exposure to only one product and may underestimate exposure to other harmful constituents. In comparison with spirometry, $\mathrm{CO}$ testing does not assess individual pulmonary function, but it is much easier to interpret, can be reliably and quickly used by staff after training, and is far less expensive as an upfront cost. $^{54}$

\section{Conclusions}

CO testing has emerged as an important medically indicated and potentially necessary procedure for clinicians offering advanced treatment to assist and document patient outcomes in smoking cessation. Further research can delineate effective ways to incorporate $\mathrm{CO}$ testing into clinical practice; promote $\mathrm{CO}$ testing as a standard of care for supporting attempts to quit smoking, cessation attempts, and relapse prevention; and demonstrate the cost benefit of reimbursement for appropriate testing.

\section{Acknowledgments}

Financial/nonfinancial disclosures: The authors have reported to CHEST the following: M. B. is the chief executive officer and cofounder of IntelliQuit. IntelliQuit develops tobacco treatment ecosystems, including a smart phone carbon monoxide monitor. None declared (A. O. G, S. P. G., C. R.-M., C. K.).

Other contributions: The authors would like to thank Jennifer Greyber, BA, for her assistance in preparing the manuscript for submission.

\section{References}

1. Middleton ET, Morice AH. Breath carbon monoxide as an indication of smoking habit. Chest. 2000;117(3):758-763.

2. Rupert DJ, Poehlman JA, Damon SA, Willliams PN. Risk and protective behaviours for residential carbon monoxide poisoning. Inj Prev. 2012;19(2):119-123.

3. Frei M, Brügger OE, Sendi P, Reichart PA, Ramseier CA, Bornstein MM. Assessment of smoking behaviour in the dental setting. A study comparing self-reported questionnaire data and exhaled carbon monoxide levels. Clin Oral Investig. 2012;16(3): 755-760.

4. Bittoun R. Carbon monoxide meter: the essential clinical tool-the 'stethoscope' - of smoking cessation. J Smok Cessat. 2008;3(02): 69-70.

5. Michie S, Hyder N, Walia A, West R. Development of a taxonomy of behavior change techniques used in individual behavioral support for smoking cessation. Addict Behav. 2011;36(4):315-319.

6. Gomez C, Berlin I, Marquis P, Delcroix M. Expired air carbon monoxide concentration in mothers and their spouses above $5 \mathrm{ppm}$ is associated with decreased fetal growth. Prev Med. 2005;40(1): $10-15$.

7. Sandberg A, Sköld CM, Grunewald J, Eklund A, Wheelock ÅM. Assessing recent smoking status by measuring exhaled carbon monoxide levels. PLoS One. 2011;6(12):e28864.

8. Benowitz NL, Peyton J III, Ahijevych K, et al. SRNT Subcommittee on Biochemical Verification. Biochemical verification of tobacco use and cessation. Nicotine Tob Res. 2002;4(2):149-159.

9. Thomsen T, Tønnesen H, Møller AM. Effect of preoperative smoking cessation interventions on postoperative complications and smoking cessation. Br J Surg. 2009;96(5):451-461.

10. Marrone GF, Shakleya DM, Scheidweiler KB, Singleton EG, Huestis MA, Heishman SJ. Relative performance of common biochemical indicators in detecting cigarette smoking. Addiction. 2011;106(7):1325-1334.

11. Singh S, Saumya M, Saini A, Mittal V, Singh UV, Singh V. Breath carbon monoxide levels in different forms of smoking. Indian J Chest Dis Allied Sci. 2011;53(1):25-28.

12. Ramesh D, Haney M, Cooper ZD. Marijuana's dose-dependent effects in daily marijuana smokers. Exp Clin Psychopharmacol. 2013;21(4):287-293.

13. Ryter SW, Choi AM. Carbon monoxide in exhaled breath testing and therapeutics. J Breath Res. 2013;7(1):017111.

14. Kobayashi M, Miyazawa N, Takeno M, et al. Circulating carbon monoxide level is elevated after sleep in patients with obstructive sleep apnea. Chest. 2008;134(5):904-910.

15. Sato S, Nishimura K, Koyama H, et al. Optimal cutoff level of breath carbon monoxide for assessing smoking status in patients with asthma and COPD. Chest. 2003;124(5):1749-1754.

16. Paredi P, Wojciech B, Invernizzi G, Kharitonov SA, Barnes PJ. Exhaled carbon monoxide levels elevated in diabetes and correlated with glucose concentration in blood: a new test for monitoring the disease? Chest. 1999;116(4):1007-1011.

17. Fritsch T, Herpen MV, Basum GV, Hering P, Mürtz M. Is exhaled carbon monoxide level associated with blood glucose level? A comparison of two breath analyzing methods. J Biomed Opt. 2008;13(3):034012.

18. Kotz D. Possible reasons for elevated carbon monoxide in selfreported ex-smokers. Nicotine Tob Res. 2012;14(8):900-901.

19. MacIntyre RO, Crapo G, Viegi DC, et al. Standardisation of the single-breath determination of carbon monoxide uptake in the lung. Eur Respir J. 2005;26:720-735.

20. Zavorsky GS, Smoliga JM, Longo LD, et al. Increased carbon monoxide clearance during exercise in humans. Med Sci Sports Exerc. 2012;44(11):2118-2124.

21. Halladay JR, Vu M, Ripley-Moffitt C, et al. Patient perspectives on tobacco use treatment in primary care. Prev Chronic Dis. 2015;12: 1-8.E14. 
22. Strasser AA, Lerman C, Sanborn PM, Pickworth WB, Feldman EA. New lower nicotine cigarettes can produce compensatory smoking and increased carbon monoxide exposure. Drug Alcohol Depend. 2007;86(2-3):294-300

23. Benowitz NL, Jacob P III, Kozlowski LT, Yu L. Influence of smoking fewer cigarettes on exposure to tar, nicotine, and carbon monoxide. N Engl J Med. 1986;315(21):1310-1313.

24. Velicer WF, Prochaska JO, Rossi JS, Snow MG. Assessing outcome in smoking cessation studies. Psychol Bull. 1992;111(1):23-41.

25. Tackett AP, Lechner WV, Meier E, et al. Biochemically verified smoking cessation and vaping beliefs among vape store customers. Addiction. 2015;110(5):868-874.

26. Klemperer EM, Hughes JR. Does the magnitude of reduction in cigarettes per day predict smoking cessation? A qualitative review. Nicotine Tob Res. 2015;18(1):88-92.

27. Akhavan S, Nguyen LC, Chan V, Saleh J, Bozic KJ. Impact of smoking cessation counseling prior to total joint arthroplasty. Orthopedics. 2017;40(2):e323-e328.

28. Brunette MF, Ferron JC, Drake RE, et al. Carbon monoxide feedback in a motivational decision support system for nicotine dependence among smokers with severe mental illnesses. J Subst Abuse Treat. 2013;45(4):319-324.

29. McClure JB. Are biomarkers a useful aid in smoking cessation? A review and analysis of the literature. Behavioral Med. 2010;27: 37-47.

30. Bedfont. Smokerlyzer range user manual. http://www.bedfont.com/ file.php?f=ZmlsZSMjMTgxMg. Updated 2016. Accessed May 12, 2016 .

31. Meredith SE, Robinson A, Erb P, et al. A mobile-phone-based breath carbon monoxide meter to detect cigarette smoking. Nicotine Tob Res. 2014;16(6):766-773.

32. Kotz D, Wagena EJ, Wesseling G. Smoking cessation practices of Dutch general practitioners, cardiologists and lung physicians. Respir Med. 2007;101(3):568-573.

33. West R, Walia A, Hyder N, Shahab L, Michie S. Behavior change techniques used by the English stop smoking services and their associations with short-term quit outcomes. Nicotine Tob Res. 2010;12(7):742-747.

34. Beard E, West R. Pilot study of the use of personal carbon monoxide monitoring to achieve radical smoking reduction. J Smok Cessat. 2012;7(01):12-17.

35. Shahab L, West R, McNeill A. A randomized controlled trial of adding expired carbon monoxide feedback to brief stop smoking advice: evaluation of cognitive and behavioral effects. Health Psychol. 2011;30(1):49-57.

36. Grant A, Ashton K, Phillips R. Foucault, surveillance and carbon monoxide testing within stop smoking services. Qual Health Res. 2015;25(7):912-922.

37. McClure JB, Ludman E, Grothaus L, Pabiniak C, Richards J, Mohelnitzky A. Immediate and short-term impact of a brief motivational smoking intervention using a biomedical risk assessment: The Get PHIT trial. Nicotine Tob Res. 2009;11:394-403.

38. Sloan M, Campbell KA, Bowker K, et al. Pregnant women's experience and views on an "opt-out" referral pathway to specialist smoking cessation support: a qualitative evaluation. Nicotine Tob Res. 2016;18(5):900-905.

39. Bize R, Burnand B, Mueller Y, Rege-Walther M, Camain JV, Cornuz J. Biomedical risk assessment as an aid for smoking cessation. Cochrane Database of Syst Rev. 2012;12:CD004705.

40. Dallery J, Raiff BR, Grabinski MJ. Internet-based contingency management to promote smoking cessation: a randomized controlled study. J Appl Behav Anal. 2013;46(4):750-764.

41. Christenhusz L, Jongh FD, Valk PV, Pieterse M, Seydel E, Palen JV. Comparison of three carbon monoxide monitors for determination of smoking status in smokers and nonsmokers with and without COPD. J Aerosol Med. 2007;20(4): 475-483.
42. Micro Direct. CO check+ operating manual. https://mdspiro.com/ image/data/manuals/CO\%20Check\%20+.pdf. Updated 2014. Accessed May 12, 2016.

43. Micro Direct. MicroCO meter manual. https://mdspiro.com/image/ data/manuals/MicroCO\%20-\%20MC02.pdf. Updated 2014. Accessed May 12, 2016.

44. Micro Direct. SmokeCheck operating manual. https://mdspiro.com/ image/data/manuals/SmokeCheck\%20-\%20SC01.1.21.14.pdf. Updated 2012. Accessed May 12, 2016.

45. Bedfont. iCO smokerlyzer user manual. http://www.bedfont.com/ file.php?f=ZmlsZSMjMTczMw==. Updated 2015. Accessed May 12,2016

46. Vitalograph. BreathCO carbon monoxide monitor user manual. https://vitalograph.com/content/manuals/vus08508.pdf. Updated 2011. Accessed May 12, 2016.

47. Bedfont. piCO + smokerlyzer operating manual. www.bedfont.com/ file.php?f=ZmlsZSMjNzE0. Updated 2014. Accessed July 3, 2016.

48. Micro Direct. Breath CO monitors. https://mdspiro.com/index.php? route $=$ product $/$ category \&path $=70$. Updated 2016. Accessed May 12, 2016.

49. Vitalograph. BreathCO: Carbon monoxide monitor. https:// vitalograph.com/product/162449/breathco. Updated 2016. Accessed May 12, 2016.

50. Bedfont. ToxCO operating manual. http://www.bedfont.com/file. php?f=ZmlsZSMjNzEw. Updated 2014. Accessed May 12, 2016.

51. Centers for Medicare \& Medicaid Services. ICD 10. https://www cms.gov/Medicare/Coding/ICD10/index.html? redirect=/icd10. Accessed March 1, 2017

52. Manaker S. Fractional exhaled nitrous oxide: Inflamed coverage achieves remission. Chest. 2016;49:1123-1125.

53. MD Spiro. Annual physician fee schedule payment amount file. CPT Code 94250. https://mdspiro.com/image/data/PDFs/Reimbursement \%202017\%20-\%2094250.pdf. 2017. Accessed October 12, 2017.

54. Coates AL, Graham BL, McFadden RG, et al. Spirometry in primary care. Can Respir J. 2013;20:13-22.

\section{Appendix 1. Carbon Monoxide Testing Sample Procedure}

Purpose: This policy is intended to outline the procedures for the safe and appropriate use of carbon monoxide $(\mathrm{CO})$ testing.

Monitor: The $\mathrm{CO}$ monitor used in this sample procedure is the Bedfont Smokerlyzer, used in the University of North Carolina Nicotine Dependence Program.

\section{Procedure}

I. Training: All clinical staff will receive training in the health consequences of $\mathrm{CO}$ and in the proper use of the carbon monoxide monitor.

\section{Procedure}
A. Significance of CO as a harmful byproduct of smoking tobacco is explained to the patient.
B. Procedure is explained or demonstrated and questions are answered.
C. Counselor hands the $\mathrm{CO}$ monitor to the patient.
D. Patient is instructed to take deep breath and hold for 15 seconds. 
E. If patient is unable to hold breath for a full 15 seconds, patient holds breath for whatever length of time is comfortably tolerable.

F. After 15 seconds, patient makes seal with lips over the disposable mouthpiece and exhales.

III. Equipment maintenance
A. All monitors should be registered with facilities as indicated by a barcode with an electronic product code number.
B. Calibration: Monitors will be calibrated at least every 6 months.
C. Treatment program supervisor ensures that maintenance is done and documentation is maintained.

\section{Safety/infection control}
A. A new disposable cardboard mouthpiece is used for each person taking the test, as they are designed

for one use only. Mouthpieces fit into a connecting device (T-piece) to the CO monitor. Each patient should blow into the disposal cardboard mouthpiece, which will be disposed of after testing.

B. Disposal mouthpiece will be removed after the test using a germicidal disposable cloth. Both will be discarded.

C. The clinician has the discretion of wearing latex gloves during the $\mathrm{CO}$ testing. Gloves should be available in every clinical office.

D. A T-piece on each CO monitor is used to "trap" a breath sample between two nonreturn valves.

These valves also stop people "'sucking back" air through this T-piece. Each T-piece should be replaced at least each month according to manufacturer guidelines.

E. After each use, the CO monitor should be wiped with an antigermicidal cloth. 